\title{
Ways to Resolve Global Problem of Collection, Conveyance and Disposal of Hazardous Medical Wastes in Ukraine
}

\author{
N.M. Myronenko, O.O. Stephan, L.O. Kozhura
}

\begin{abstract}
This scientific paper studies the procedure and specific aspects of collection, conveyance and disposal of hazardous medical wastes in Ukraine. Drawing on analysis of the state of matters in the sphere of collection, conveyance and disposal of hazardous medical wastes in Ukraine, we proposed effective ways to resolve this problem. With a view to improve the procedure for collection, conveyance and disposal of hazardous medical wastes in Ukraine, we proposed, firstly, to strengthen public control over the state procurement with the help of "DoZor public", an online platform, where everyone can provide a feedback to a state customer or supplier, society or law enforcement authorities regarding the conducted procurement procedure, discuss and evaluate the terms of a particular purchase, and analyze purchases of a particular customer. Secondly, insufficient control by the state also provokes emergence of such situations. In this context, it is expedient to lift the moratorium on inspections of business entities by the controlling bodies. It has been established that the main sources of generation of pharmaceutical and medical wastes in Ukraine are: medical waste from hospitals, health centers, health resorts, outpatient clinics, etc.; materials from laboratories and pharmaceutical manufacturing enterprises; tissues and body parts from surgical theaters; expired drug products; medical devices; leftover medicines in the form of liquid medicines, pills, solutions, etc. in a household setting; waste from pharmacies, pharmacy branches and pharmacy kiosks; packaging materials from drug products, etc. The author has investigated the main methods employed for destruction of poor-quality drugs in the form of solid products, powders (pills, capsules, granules, powders for injection), semisolid drugs (creams, gels, ointments) by means of encapsulation, inertization or high-temperature incineration.
\end{abstract}

Keywords : health care, medicines, turnover of medicines, medical waste, hazardous waste, collection, conveyance, disposal.

Revised Manuscript Received on November 15, 2019 * Correspondence Author

N.M. Myronenko, Doctor of Law, Professor, Associate Fellow of the National Academy of Legal Sciences of Ukraine of the Research Institute of Intellectual Property of the National Academy of Legal Sciences of Ukraine, Deputy Research Director, mironenko_nm@ukr.net,+380955041912

O.O. Stephan, Doctor of Law, Research Institute of Intellectual Property of the National Academy of Legal Sciences of Ukraine, mironenko_nm@ukr.net, +380955041912

L.O. Kozhura Cand. Sc. Law, Assistant Professor, State Higher Educational Establishment Vadym Hetman National Economic University, Professor of Law Theory and History Department, lepel@ukr.net, $+380672203265$

\section{INTRODUCTION}

Over the past decades, the growing uncontrolled presence of leftover medicines and their metabolites in the environment has become a matter of global concern. The problem of disposal and neutralization of waste is looming large in all parts of the world and in Ukraine in particular. According to statistics, one Ukrainian produces about a ton of waste per year, of which less than a third is utilized [1].

\section{MATERIALS AND METHODS}

The methodology of the work conducted is based on the use of general scientific and special scientific methods and tools of scientific cognition. The comparative legal method was employed to analyze the specifics of collection, conveyance and disposal of hazardous medical waste in Ukraine and European countries. The technical method allowed comprehensive examination of current state of legislative and legal and regulatory framework of collection, conveyance and disposal of hazardous medical waste, to identify drawbacks of the specified type of activity, gaps, contradictions and miscalculations, as well as to elaborate recommendations for their elimination. Results of the study showed that collection, conveyance and disposal of hazardous medical waste have to be improved. The authors proposed means for improvement of this branch. Scope of application of results. Results of this study will be applied in practical and scientific activities in the sphere of medicines turnover.

The purpose of this paper is to determine the ways to tackle the global problem of collection, conveyance and disposal of hazardous medical wastes in Ukraine. The subject of the study is collection, conveyance and disposal of hazardous medical wastes in Ukraine. Scope of research as regards to collection, conveyance and disposal of hazardous medical waste in Ukraine was also a subject of scientific papers of Z.S. Gladun, O.G. Kuzmenko, V.K. Kolpakova, V.F. Moskalenko, S.G. Stetsenko, O.G. Strelchenko, G.T. Tereshkevich, T.V. Pedchenko, V.M. Rudoj, O.V. Lubinets, I.Ya. Senyuta, O.G. Rohova, V.M. Tretyakova, Makhmudova E.Yu. Presently, the world continues to face growing waste management challenges, and therefore the subject of this study remains a critical issue. 


\section{RESULTS}

The problem of pharmaceutical waste recycling and destruction is yet to be resolved in Ukraine. Today there is no holistic, well-adjusted system that would cover all stages of the waste handling. There emerged a collision in the current legislation that exercises legal regulation of utilization and destruction of pharmaceutical waste. Thus, clause 4 of Resolution of the Cabinet of Ministers of Ukraine "On approval of licensing terms for carrying out economic activity in hazardous waste management" [2] states that the Licensing terms apply to all economic entities, regardless of their organizational and legal form and form of ownership, that fully or partially carry out or intend to carry out economic activity in hazardous waste management. Thus, in pursuance of this norm, all medical and pharmaceutical institutions should hold a respective license for this type of activity, in our case, a license for utilization and destruction of drug products. Accordingly, if to start from villages, all medical and obstetrical stations must have the license, since otherwise they are not adhering to requirements of the Licensing Terms. And the situation is the same in most health care facilities.

At the same time, it is worth noting that as of today Order of the Ministry of Health of Ukraine "On Approval of State Epidemiological Rules and Standards for Medical Waste Management" [3] stipulates requirements for management of medical waste (collection, conveyance, storage, sorting, processing (recycling), utilization, removal, decontamination, dumping, destruction) in health care facilities. However, these Rules do not apply to management of medical waste generated by enterprises that manufacture pharmaceutical products and medical wastes created in households.

Noteworthy, according to requirements of Article 2 of Law of Ukraine "On medicines", poor-quality medicines, expired medicines shall be subject to salvaging, destruction, etc. Requirements of Order of the Ministry of Health of Ukraine No. 242 dd. April 24, 2015 "On Approval of Rules for Utilization and Destruction of Medicines" have set up utilization and destruction of pharmaceutical waste of pharmaceutical plants and factories, while problems of collection and neutralization of expired medicinal products or leftover drugs in Ukraine remains unresolved. Since no mechanism of utilization and destruction of medicinal products has been elaborated, the population, pharmacies and other pharmaceutical establishments are acting at their own discretion, that is they are making a minimum effort, and all pharmaceutical waste is discarded into trash bins or drained into the sewage system.

\section{DISCUSSION}

Presentation of the main results and their justification. The pharmaceutical industry is one of the biggest environmental polluters, who year-by-year is increasing production of medicines by several million packages and is expanding the product range. The ecologists have proved that even an insignificant amount of drug products that enter water bodies and soil with sewage produce an extremely negative influence on the water bodies and soil. Medicines that are poorly soluble in water, such as anti-inflammatory agents, anesthetics, antibiotics, hormones are weakly biodegradable; they pass through the treatment plants unchanged and enter soil and environmental waters [1].
Medical and pharmaceutical wastes are specific by nature. In particular, the poor-quality medicines that have not been properly disposed may exert adverse biological impact on plants and animals, as well as produce an indirect effect through drinking water and food products, causing allergization of the body and formation of drug resistance. Antibiotics, antiseptics, cytostatics pose a particular threat, since these agents, when released into the environment, can significantly disrupt the ecological balance. Medical wastes that contain infected material, living infectious agents in the form of vaccines, can become a source of propagation of infectious diseases. Hormonal agents that enter water and soil can adversely affect the pattern of development in animals [2].

In retrospect of problematics of medicines utilization, it is worth mentioning that efforts at detecting drug products in natural surface waters, samples of wastewater before and after their purification began in the 1970's and revealed that natural and synthetic steroid hormones are fairly stable in the environment $[4$, p. $368 ; 5$, p. 173$]$. Since the mid-80's, the problem of pollution of environment with pharmaceuticals is spurring great concern. The endocrine-disrupting drugs, lipid-lowering agents and other non-hormonal drug products that exhibit biological effects on living organisms of the aquatic environment at extremely low concentrations (ng/l) are in the focus of attention [6, p. 368; 7, p. 173]. Since the 90 's, the spectrum of experimental classes of drug products was significantly expanded. The analytical studies conducted in the USA and Europe on identification of various drugs and their metabolites in soil, water, sewage systems, effluents after treatment in treatment plants, surface water bodies, groundwater and drinking water showed their significant concentrations $(\mu \mathrm{g} / \mathrm{l})$ in the samples of purified sewage and surface water [8, p. 807]. This is due to the fact that modern sewage treatment technologies employed in wastewater treatment plants are not suitable for removal and neutralization of medicinal products [9, p. 909]. Most drug products are present in surface water at concentrations of 1 $\mathrm{ng} / \mathrm{l}-1 \mu \mathrm{g} / \mathrm{l}[10, \mathrm{p} .10]$. Studies conducted in Germany have shown that under appropriate conditions such drug products as clofibric acid, carbamazepine and iodinated contrast agents pass through the soil and are detected in samples of groundwater. Groundwater of some regions in the USA and Germany contained more than thirty drug products (antibiotics, cardiac, antipyretic and analgesic agents, etc.) in concentrations that were dangerous to human health $[11, \mathrm{p}$. $137 ; 12$, p. 274]. Insignificant concentrations (trace amounts) of certain classes of drug products were found in drinking water as well [13, p. 1062].

In contrast to other chemical pollutants, such as organochlorine pesticides, polychlorinated biphenyls, pharmaceutical products are intended for individual use, and their entry to the environment has no geographical or climatic restraints. They are constantly penetrating the environment during the life of a person, while other pollutants (i.e. chemicals that pollute the environment) are used sporadically and have higher spatial heterogeneity. Most drugs, unlike the persistent organic pollutants (POPs), are not bioaccumulative and volatile. But with prolonged and continuous penetration to the environment, even drugs with a low persistence (that is, low ability of a condition to exist longer than the process 
that created it) can produce effects similar to those produced by the persistent pollutants, because the rate of their transformation and removal is offset by the rate and continuity of penetration [14].

When used by patients, drugs, together with their chemical precursors, transformation products and metabolites, enter the environment through the sewage system in unnormalized amounts, depending on the volume of consumption. Some drugs are excreted from the body substantially unchanged. Others are metabolized in the body by oxidases of a mixed function to more polar compounds that are easily excreted from the body. In this case, the degree of metabolization depends on several factors: individual characteristics of the patient, duration of the course of administration and dose. Moreover, the expired medicines and leftover drugs are often disposed of to the sewage system. At the same time, other ways of environmental pollution with pharmaceuticals are the use of drug products in veterinary medicine as growth promoters in livestock, poultry and fish farms. As a result of use of liquid decomposed dung, hen manure or silty mud from treatment plants as fertilizers, these drugs directly penetrate the environment. Going through the soil, they enter underground water, and medicines used in fish farms directly enter surface water. Moreover, since the household garbage is not sorted, there is a risk of entry of medicines to the environment from domestic waste landfills [15, p. 79].

Pursuant to the Basel Convention, joined by Ukraine in 1999, medical and pharmaceutical wastes are classified as "hazardous waste" and shall be subject to proper disposal. "Hazardous waste" stands for waste with such physical, chemical, biological or other hazardous properties that pose or are likely to pose a significant hazard to the environment and human health and that require special methods and means of handling.

Medicinal products that are not subject to further use and, therefore, shall be utilized and neutralized, include: poor-quality medicines, including expired medicines; unregistered drugs; medicinal products that have been exposed to mechanical, chemical, physical, biological or another influence as a result of which their further use is impossible; counterfeit medicines, etc. [16].

It is also worth noting that based on the hazards level and negative impact on the environment, medical wastes are divided into classes as follows: A - posing no hazard; B potentially hazardous; B - extremely hazardous; $\mathrm{G}$ - posing toxicological hazard; $\mathrm{D}$ - posing radiological hazard [17].

Medical waste is accumulated in hospitals, pharmacological enterprises, companies and households (for example, spoiled medicines or bandages, expired medicines, etc.). Accordingly, the main sources of pharmaceutical and medical waste generation in Ukraine are:

- medical waste from hospitals, clinics, health resorts, outpatient clinics, etc.;

- materials from laboratories and pharmaceutical manufacturers;

- tissue and body parts from surgical theaters;

- expired drug products;

- medical devices;

- leftover medicines in the form of liquid medicines, pills, solutions, etc. in a household setting;

- waste from pharmacies, pharmacy branches and pharmacy kiosks;
- packaging materials from drug products, etc.

Requirements for management of medical waste of different categories differ accordingly in methods of destruction and utilization.

Presently, the problem of utilization of poor-quality medicines and expired drugs is looming large. Thus, hazard class 3 wastes, i.e. moderately hazardous drugs, can be dumped at solid domestic waste landfills, while hazard class 2 wastes, i.e. high-risk drugs, must be disposed of using special methods [18]. The methods employed for utilization and destruction of poor-quality medicines comprise: encapsulation (transformation of poor-quality medicines into an enclosed-volume monolith with the help of astringent substances); inertization (transformation of poor-quality medicines into a monolith with the help of astringent substances and further shredding and dispersal of the monoliths); thermal methods (high-temperature incineration, pyrolysis); chemical neutralization; autoclaving (for preparations containing living cells and spores of microorganisms); method of dilution with water and drainage into a municipal collector (for low-hazard preparations). Methods of encapsulation, inertization or high-temperature incineration are used to destruct poor-quality drugs in the form of solid products, powders (pills, capsules, granules, powders for injection), semisolid drugs (creams, gels, ointments). Noteworthy, most of the methods for utilization of pharmaceutical waste have a number of disadvantages. For example, methods involving the use of chemicals can lead to formation of environmentally hazardous chemical compounds, and equipment for thermal methods is quite expensive because it necessitates for construction of complex gas purification systems, and therefore this method is less affordable for the enterprises [20].

Large pharmaceutical enterprises usually have licenses authorizing them to utilize and dispose of poor-quality medicines that have been produced as a result of violation of manufacturing technology or expired medicines received back from the buyers in accordance with the contractual terms [2]. In case of detection of poor-quality medications, pharmacy establishments either return them to the supplier (if this is provided for by the contract), or transfer the poor-quality medicines to specialized enterprises licensed to conduct operations in the field of hazardous waste management [2].

The problem of utilization and disposal of pharmaceutical waste generated by the population in Ukraine is yet to be resolved and brought under regulatory control. The population is not aware of the dangers entailed by improper medical waste management, there is no information regarding possible methods of disposal of poor-quality medicines and expired drugs in a household setting, no conditions for receiving pharmaceutical waste from the population have been created for its further transfer to the relevant entities licensed to conduct operations in the field of hazardous waste management [2].

Attention should be paid to the awareness of population about environmental damage inflicted by medicines that enter wastewater, soils, air, etc in different quantities, with different chemical composition, and their chemical reactions. For example, the European practice and world practice of the developed countries, as part of 
responsible management of specific wastes, obliges the population to bring such drugs to a collection station or to a pharmacy that exercises this function in the region. However, Ukraine has no collection stations and the population is yet to become aware of this problem.

As a result, situation with regard to management of medical waste and hazardous medical waste is getting critical. Environmentalists are raising the alarm because such waste is to be disinfected and burned, rather than dumped in conventional landfills. However, the major share of medical waste is conveyed to the conventional landfills, thus critically aggravating the risk of epidemiological hazard.

In support of the above stated, it should be noted that there are frequent cases of careless treatment of medical waste. Thus, illegal landfills of medical waste are often discovered in forest belts; tens and hundreds of bags with medicines, sharps, containers and other waste of organic origin, with their packages reading "Especially hazardous" and "B category" are found in conventional landfills. "B category" includes waste from hospital infectious departments, materials from laboratories, pharmaceutical manufactures, tissues and even body parts from surgical theaters. Such waste is discarded in the open air, near a village, a river, a place of mass gathering of children (urban-type settlement Demydiv, Kyivska oblast, year 2017). [19]

Repeated cases of improper storage and disposal of medical waste include delivery of medical wastes to the territory of enterprises allegedly licensed for collection, conveyance and disposal of hazardous medical waste, and storage of the wastes on the territory of the industrial site, which is a gross violation of norms of current legislation (city of Zaporizhia, 2017). Inspection of these territories by the law enforcement officers has revealed 2.5 tons of used medical instruments, diagnostic and disinfecting agents, batteries, devices and equipment containing mercury and heavy metals, 1.5 tons of organic medical waste, objects contaminated with biological fluids, wastes from medical establishments and microbiological laboratories that worked with causative agents of active form of tuberculosis. Similar cases were recorded in other regions of Ukraine (Lvivska, Kyivska, Cherkaska, Khmelnytska, etc.).

Noteworthy, economic activity on hazardous waste management in Ukraine is subject to licensing. The respective Licensing Terms have been approved by Resolution of the Cabinet of Ministers of Ukraine dd. July 13, 2016, under the number 446. At the same time, these Licensing Terms do not apply to economic activity in conveyance of hazardous wastes. Such activity must meet requirements established by the Licensing Terms for economic activity in conveyance of passengers, hazardous cargo and hazardous wastes by motor vehicles, international transportation of passengers and cargo by motor vehicles. In other words, an enterprise that carries out operations in the field of hazardous waste management (collection, storage, disposal), and waste conveyance should have 2 licenses issued by the Ministry of Ecology and Natural Resources of Ukraine and the State Service of Ukraine for Transport Safety, respectively. However, in practice, it turns out that the licensees do not always adhere to the legislation in the field of hazardous waste management, ignore the need to obtain permits, carry out unauthorized discarding of hazardous wastes. The question arises, what is the reason behind this situation? In view of a 3-year moratorium on inspections of business entities by the controlling bodies, the unconscientious owners of enterprises are experiencing lack of oversight. As a result of the ban on inspections in the field of hazardous waste management, it is impossible to trace the final result, which leads to removal of the waste to the household waste landfills or formation of unauthorized dumps in forest belts, draws and coastal protective strips of reservoirs, etc. Thus, in practice, introduction of moratorium has led to failure of certain entrepreneurs to comply with requirements of environmental legislation, hazardous waste management legislation and a catastrophic deterioration of ecological situation in Ukraine.

Year 2018 saw introduction of partial moratorium on scheduled inspections of enterprises. In February 2018, Resolution of the Cabinet of Ministers of Ukraine dd. December18, 2017 No. 1104 "On approval of the list of state supervision (control) authorities not covered by the law of Ukraine "On provisional particularities of implementation of state supervision (control) measures in the sphere of economic activity" came into operation. List of control authorities that are not covered by the moratorium included the Ministry of Ecology and Natural Resources of Ukraine. To the contrary, the State Service of Ukraine on Transport Safety is not authorized to carry out scheduled inspections of licensees in 2018.

Another aspect - careless handling of medical wastes from certain health facilities.

Licensing terms for economic activities in medical practice mention medical waste management in health facilities only once. Thus, the licensee, among other things, is obliged to adhere to the established sanitary norms, in particular those concerning prevention of intra-hospital infections, removal, destruction of household garbage and medical wastes. General requirements for medical waste management in health facilities are established by the State Epidemiological Rules and Standards for Medical Waste Management, approved by the Order of the Ministry of Health of Ukraine dd. June 8, 2015, No. 325.

This document provides that medical waste posing threat to human health shall not be accumulated, temporarily stored, conveyed, and destroyed together with other wastes. Besides, after decontamination, medical waste shall be conveyed to enterprises licensed to carry out hazardous waste management operations that have properly certified equipment. A large part of these wastes can be toxic, flammable, radioactive, capable of provoking infectious diseases, and therefore is posing a great hazard during collection, conveyance and disposal. It is therefore quite rational to forward such waste for utilization to specialized utilization enterprises that have a relevant license.

At this point, the question arises: why health care facilities sometimes violate environmental legislation and legislation in the field of hazardous waste management?

To answer this question, it is necessary to mention that health care facilities must sign waste management contracts with enterprises licensed to conduct operations in the field of hazardous waste management. As a rule, such contracts are concluded on the basis of conducted tenders for procurement of services in the field of radioactive, toxic, medical and hazardous waste management. The criterion for selection of the winner is the lowest price offered for the services. However, having reviewed the tender statistics in ProZorro 
electronic public procurement system, we have seen that tenders for disposal of medical waste are often won by companies that neither have a license, nor appropriate facilities for medical waste disposal, nor employees with proper qualification, knowledge and experience. This information can easily be verified in the Licensing Register (hazardous waste management) of the Ministry of Ecology and Natural Resources. Such enterprises have the right to collect, store and transport waste, but not to dispose of it. In some cases these companies have a contract with an enterprise that has the right to carry out this kind of activity. Such state of things does not prevent these companies from winning the tenders for medical waste disposal on a regular basis.

The procurement item is services in conveyance and disposal of wastes of medical origin. The tender participant must correspond to the procurement item and have all the permits as regards to this procurement item. However, there are cases when the customer, in disregard for requirements of Order of the Ministry of Health of Ukraine No. 325 "On Approval of State Epidemiological Rules and Standards for Medical Waste Management" as related to conveyance of Category B wastes (organic waste from patients, sharps) to the licensed enterprises for carrying out operations in the field of hazardous waste management, who have properly certificated equipment, admits to the procurement procedure participants with no proper license.

Analysis of tender procurements has revealed that in many cases customers, represented by health care facilities, among other things, include to the list of a participant qualification requirements availability of license of the Ministry of Ecology and Natural Resources of Ukraine for operations in the field of hazardous waste management (collection, storage, conveyance, disposal) or a contract with an enterprise that has the right to carry out this activity, with the provision of all the permits.

So why do healthcare facilities ignore current legislation, admit participants that fail to meet the established requirements to the tenders? As it was already noted, the key criterion for selecting the winner is the lowest price offered. The financial condition of most healthcare facilities leaves much to be desired. Therefore, the expenditures on payment for the services of enterprises that utilize medical waste are not provided for in sufficient volumes.

In our opinion, firstly, it is expedient to strengthen public control over public procurement using "DoZor public", an online platform, where everyone can provide a feedback to a state customer or supplier, society or law enforcement authorities regarding the conducted procurement procedure, discuss and evaluate the terms of a particular purchase, and analyze purchases of a particular customer.

Secondly, insufficient control by the state also provokes emergence of such situations. In this context, it is expedient to lift the moratorium on inspections of business entities by the controlling bodies.

In view of the current situation, in November 2017, the Government approved the National Strategy for Waste Management in Ukraine till 2030. Particular attention was paid to the issue of medical waste management.

The main problems in the field of medical waste management are: low level of medical waste management in health care facilities; lack of necessary means and premises for collection, conveyance and safe temporary storage of infectious wastes within the health care facilities; lack of refrigerating equipment for storage of wastes at low temperatures; lack of appropriate containers and packages; limited opportunities in purchase of high-quality equipment for medical waste treatment.

However, the state recognizes that a significant proportion of medical waste is removed to disposal sites and unauthorized landfills as a result of irresponsibility of healthcare providers in the health care facilities, insufficiency and inaccessibility of facilities for the treatment and disposal of medical waste. The reason for this is the extremely limited financial resources that constitute a potent constraining factor impeding improvement of the medical waste management system. The state of the national economy in recent years has significantly influenced the financial provision of the medical sector, and it is clear that attraction of financial resources necessary to implement proper medical waste management system is a very complicated task.

Another negative factor is that more and more firms without material and technical resources of their own required for collection, conveyance and disposal of hazardous medical waste are winning tenders while dumping at the market.

\section{V.RESULTS}

We think that in order to address the vexed problem that has emerged in Ukraine with regard to collection, conveyance and disposal of hazardous medical waste, it is necessary:

first, to create a unified information base for monitoring and control of waste management, which will contain information on the nomenclature and amount of waste generated, recycled, disposed of and removed. Besides, this base shall include economic entities that are providing such services. Creation of the National Register of sources of waste generation, facilities carrying out activities in the sphere of waste treatment and accounting systems of business entities will become an important control tool;

second, it is expedient to propose a dual use of medicines due to limited governmental funding of medical waste management and to follow the model of European countries (for example, acetaminophen (paracetamol) is a common anesthetic that has been successfully used to control population of brown wood snakes in the US; caffeine is a stimulator of the central nervous system and in concentrations above $0.5 \%$ it is used as a repellent and a means for eradication of snails and slugs; anticoagulant warfarin is a component of the first generation rodenticides and is used as a poison for rodents (rats, mice), etc.);

third, introduction and observance of Good Manufacturing Practices (GMP) in the pharmaceutical industry, which requires maintenance of current level of medicines manufacturing with minimization of pharmaceutical waste production is one of the ways to reduce amounts of medicines and hazardous chemicals that enter the environment;

fourth, to oblige a pharmacist to establish a safe method of medicines disposal in hospital and/or pharmacy of the community, in order to encourage patients and the public to return their expired or unnecessary medicines and medical devices. Besides, it is expedient to oblige pharmacists to provide patients with relevant information on safe disposal of expired or unnecessary medicines;

fifth, to improve the regulatory framework of Ukraine within the spectrum of 
issues related to utilization and disposal of pharmaceutical waste, which would necessitate elaboration of a comprehensive approach to the regulation of utilization and disposal of pharmaceutical wastes, in particular in order to immediately establish a proper system of medical waste management and terminate the negative impact of medical waste on the environment and human health.

\section{DISCUSSION}

Based on the study conducted, it was established that today 480-500 thousand tons of medical waste, including drug products, is generated annually in Ukraine, of which 200-220 thousand tons are hazardous; these include sharps, infectious waste, anatomical and pathological waste, outdated or expired chemical products, pharmaceuticals, medicines and radioactive materials. Hazardous substances contained in medical waste negatively affect the environment and human health as they accumulate at high concentrations in soil and water bodies, thus disturbing the natural ecosystem; they exhibit resistance as compared to the natural components, negatively affect natural resources (especially the aquatic fauna) even at low concentrations; provoke propagation of infectious and non-infectious diseases (may cause serious diseases such as cancer, AIDS, viral hepatitis, meningitis, typhoid fever, rabies, etc.), lead to release of other physiologically active substances; negatively affect living organisms and may lead to unpredictable consequences [20, p. 6].

\section{CONCLUSION}

Based on the above, the paper has proved the necessity of elaboration and adoption of Law of Ukraine "On utilization of medicines, medical waste, medical devices and other biological materials", which will provide for general principles for addressing the following issues: subjects of collection/acceptance of pharmaceutical waste from the population, algorithm for collection/acceptance of pharmaceutical waste from the population; peculiarities of carrying out awareness educational with the population as related to the necessity of responsible approach to collection, utilization and disposal of pharmaceutical waste; development of a system of control over utilization and disposal of pharmaceutical waste generated by the population; public control over acquisition of licenses for carrying out this type of work and control over availability of special equipment for collection, conveyance and disposal of hazardous medical waste; legal liability for violation of norms established for utilization of medicines, medical wastes, medical devices and other biological materials.

\section{FINANCIAL DISCLOSURE}

The introduction of a new financing model for collection, conveyance and disposal of hazardous medical waste in Ukraine will enable: first, to preserve the health of the nation; and second, to create specialized enterprises for collection, conveyance and disposal of hazardous medical waste in Ukraine, since the experience of the European countries has demonstrated that this activity is not only safe, it can be profitable as well.

\section{ACKNOWLEDGEMENT}

Low level of medical waste treatment confirms the urgency of problem of collection, conveyance and disposal of hazardous medical waste in Ukraine. The statistics presented in this article showed that presently collection, conveyance and disposal of hazardous medical waste in Ukraine is in dire state, which provokes occurrence of unauthorized medical waste dumps, propagation of infectious diseases among the population, emergence of environmental problems.

\section{REFERENCES}

1. O. O. Drozdova. To the issue of utilization and neutralization of pharmaceutical waste in Ukraine / O. O. Drozdova, L. V. Bondareva // Pharmacy of the XXI century: trends and prospects: materials of the VIII National Congress of Pharmacists of Ukraine, Kharkiv, September 13-16, 2016, Kharkiv, 2016. V. 1. P. 348-349.

2. On approval of Licensing terms for carrying out economic activity in hazardous waste management: Resolution of the Cabinet of Ministers of Ukraine dd. July 13, 2016, No. 446.

3. On approval of the State Epidemiological Rules and Standards for Medical Waste Management: Order of the Ministry of Health of Ukraine dd. June 8, 2015, No. 325.

4. Tabak H.H., Bunch R.L. Steroid hormones as water pollutants // Developments in industrial microbiology. 2015. V. 11. P. 367-376.

5. Temes T, Wilken R.L. Drugs and hormones as pollutants of the aquatic environment: determination and ecotoxicological impacts // Sci. total environ. 2016. V. 225, №1-2. P. 170-186.

6. Tabak H.H., Bunch R.L. Steroid hormones as water pollutants // Developments in industrial microbiology. 2015. V. 11. P. 367-376.

7. Temes T, Wilken R.L. Drugs and hormones as pollutants of the aquatic environment: determination and ecotoxicological impacts // Sci. total environ. 2016. V. 225, №1-2. P. 170-186.

8. Kummerer K. Drugs, diagnostic agents and disinfectants for human use and their emission into waste water - a review // Chemosphere, 2000, V. 41, P. 805-814

9. Daughton C.G., Ternes T.A. Pharmaceuticals and personal care products in the environment: agents of subtle change // Environ. health persp. (Supplement, 6). 1999. V. 107. P. 907-938.

10. Richardson M.L.,Bowron J.M. The fate of pharmaceutical chemicals in the aquatic environment // J. Pharm. Pharmacol. 1985. V. 37. P. $1-12$.

11. Boyd GR, Reemtsma H, Grimm DA, Mitra S. Pharmaceuticals and personal care products (PPCPs) in surface and treated waters of Louisiana, USA and Ontario, Canada // Sci. Total. Environ. 2003. V. 311, №1-3. P. 135-149.

12. Heberer T, Schmidt-Baumler K, Stan H-J. Occurrence and distribution of organic contaminants in the aquatic system in Berlin. Part I: Drug residues and other polar contaminants in Berlin surface and ground water // Acta Hydrochim Hydrobiol. 1998. V. 26, №5. P. 272-278.

13. Tixier C, Singer HP, Oellers S, Muller SR. Occurrence and fate of carbamazepine, clofibric acid, diclofenac, ibuprofen, ketoprofen, and naproxen in surface waters // Environ Sci Technol. 2003. V. 37, №6. P. 1061-1068.

14. Yu. V. Bardik. Ecological-hygienic and toxicological problems of life activity / Yu. V. Bardik, O. O. Bobylova // Suchasni problemy toksykolohii. 2005. No. 4. P. 33-36.

15. A.M. Serdyuk. Pharmaceutical waste: problems of management and solutions / A.M. Serdyuk, Yu.V. Bardik, N.M. Koval / Dovkillia ta zdorovia. 2004. No. 3 (30). Pp. 77-80.

16. S.M. Kovalenko. Topicality of utilization and destruction of poor-quality medicines / S. M. Kovalenko // Pharmacy of the XXI century: trends and prospects: materials of the VIII National Congress of Pharmacists of Ukraine, Kharkiv, September 13-16, 2016, Kharkiv, 2016. V.1. P. 258.

17. Medical waste. Url http://er-tec.com.ua/?p=2834

18. On Approval of requirements to employers for protection of employees from harmful impact of chemicals: Order of the Ministry of Emergency Situation of Ukraine dd. March 22, 2012 No. 627 // Official Bulletin of Ukraine. 2012. № 30. Art. 290. 
19. Notifications to the General Directorate of the National Police in the Kyivska oblast. URL.www. permalink.php?story_fbid $=1460841557304345 \& i d=190134267708$

20. T.A. Safranov. The problem of classification and treatment of medical waste in Ukraine / T.A. Safranov, T.P. Shanina, T.I. Panchenko // Journal of the Odessa State Ecological University, 2015, No. 19. P. 6-11.

\section{AUTHORS PROFILE}

N.M. Myronenko , Doctor of Law, Professor, Associate Fellow of the National Academy of Legal Sciences of Ukraine of the Research Institute of Intellectual Property of the National Academy of Legal Sciences of Ukraine, Deputy Research Director, mironenko_nm@ukr.net, +380955041912

O.O. Stephan, Doctor of Law, Research Institute of Intellectual Property of the National Academy of Legal Sciences of Ukraine, mironenko_nm@ukr.net, +380955041912

L.O. Kozhura Cand. Sc. Law, Assistant Professor, State Higher Educational Establishment Vadym Hetman National Economic University, Professor of Law Theory and History Department, lepel@ukr.net, $+380672203265$ 